\title{
EVALUATION OF OVERALL EQUIPMENT EFFECTIVENESS IN DEVELOPING COUNTRY IN CRANKSHAFT MANUFACTURING
}

Samira Gholizadeh ${ }^{1}$

${ }^{1}$ Affiliation not available

January 20, 2022

\section{Hosted file}

Evaluation of overall equipment effectiveness in developing country.pdf available https://authorea.com/users/441662/articles/553378-evaluation-of-overall-equipmenteffectiveness-in-developing-country-in-crankshaft-manufacturing 